\title{
A Dynamic Investigation of Foreign Direct Investment and Poverty Reduction in Mauritius
}

\author{
Sheereen Fauzel, Boopen Seetanah, Raja Vinesh Sannassee \\ University of Mauritius, Réduit, Mauritius \\ Email:s.fauzel@uom.ac.mu,b.seetanah@uom.ac.mu,rvsan@uom.ac.mu
}

Received 23 February 2016; accepted 24 April 2016; published 27 April 2016

Copyright (C) 2016 by authors and Scientific Research Publishing Inc.

This work is licensed under the Creative Commons Attribution International License (CC BY). http://creativecommons.org/licenses/by/4.0/

(c) (i) Open Access

\begin{abstract}
The focus of this study is to investigate the extent to which FDI flowing in Mauritius reduces poverty or increases welfare by using time series data for the period 1980-2013. This study methodologically departs from the existing ones as it uses a dynamic vector autoregressive model that ensures the dynamic behaviour of the time series under consideration is properly captured, while simultaneously catering for endogeneity and causality issues. Any feedback and indirect effects which might be present will also be detected within the VAR/VECM framework. The results show that indeed FDI has contributed to poverty reduction; albeit the magnitude of the coefficient is relatively smaller in the short run as compared to the long run. Also a uni-directional causality is observed between FDI and poverty reduction. Furthermore, the results confirm the fact that FDI reduces poverty through the employment channel. Other important factors contributing to a reduction in poverty according to this study is an increase in government spending as well as trade openness. Whereas, higher debt is observed to increase the level of poverty.
\end{abstract}

\section{Keywords}

FDI, Poverty Reduction, HDI, VECM

\section{Introduction}

Poverty in Mauritius is mainly related to social exclusion. According to the World Bank, poverty level is relatively low in the country as compared to other developing countries. However, the main concern is the pockets of poverty that keep on being present in Mauritius. On the other side, however, Mauritius has already met or is highly likely to meet all of the Millennium development Goals by the end of 2015. The government has been 
adopting various poverty reduction programmes in order to alleviate poverty in Mauritius. For instance, the ministry of social security has been investing colossal amount of money to provide social benefits to the local population. The participatory approach has been used in several poverty alleviation programmes whereby the poor are empowered with the necessary skills to come out of the poverty trap. Various poverty alleviation programmes using this approach have been devised and implemented in Mauritius (Community Development and Poverty Alleviation Project, 2005).

Some of the poverty reduction programmes include "The Trust Fund for the Social Integration of the Vulnerable Groups” (TFSIVG), NEPAD-Comprehensive Africa Agriculture Development Programme Mauritius: Investment Project Profile "Community Development and Poverty Alleviation Project Community Development and Poverty Alleviation Project”. There is also the IFAD Rural Diversification Programme (RDP), comprising of two main components "Micro-Enterprises and Micro-Finance Development” and “Community Development”. However, construction of houses for the poor has been given the priority in Mauritius. Regarding the education field there are the micro credit schemes and loans to needy students' programmes. It should however be noted that the National Action Plan for Poverty Alleviation has identified the need to professionalize the social and community work for the success of poverty alleviation programmes. It states that "capacity building is critical at this level for greater efficiency”.

Public investment is identified to be very crucial to alleviate poverty. However, there is a need for more investment in order to further boost welfare in the country. Hence, one source of such investment is in terms of FDI that will help to contribute to various economic aspects of the country. For instance, the direct channel through which foreign direct investment can boost welfare and reduce poverty is through employment creation. Moreover, there are other important spillovers of FDI to the host country, in the form of technological and managerial spillovers, boost in economic growth and development, contribution to the educational sector through training, increase of government revenue through the payment of taxes and so on. Therefore, there are various transmission mechanisms through which foreign direct investment can contribute towards a reduction in poverty.

Surveying the literature, it is found that there are limited studies measuring the interplay between FDI and poverty reduction, and almost none for the case of Mauritius. As such, there is a need to investigate the implications of the dynamics of FDI on welfare or poverty reduction on the economy. In this regard, whilst it is by large recognized that there are benefits to be had from foreign firms, unfortunately however, it is also true that these foreign firms do pose certain problems in certain cases.

Hence, the present paper attempts to fill such a gap and aims at adding to the existing literature by investigating the direct and indirect relationship between FDI and poverty reduction for Mauritius. Methodologically, this study uses a rigorous dynamic time series analysis namely a dynamic Vector Error Correction Model (VECM), to carry out the proposed investigation. Such a procedure ensures that the dynamic behaviour of the time series under consideration is properly captured, while simultaneously catering for endogeneity and causality issues. Any feedback and indirect effects which might be present will also be detected within the VECM. The model also allows for the identification of any bi-directional and/or uni-directional causality between the variables of interest.

The rest of this paper is organized as follows: Section 2 reviews the literature; Section 3 provides an overview of FDI and poverty in Mauritius and Section 4 defines the research method. Section 5 discusses the findings from the study and finally in Section 6, the conclusion is presented.

\section{Literature Review}

Foreign direct investment flowing in host countries has the potential of reducing poverty through various channels. For instance, FDI has positive influences on economic growth and employment creation, improvement in technology and knowledge of the host country and also the development of human capital through the provision of training. Moreover, foreign investments contribute to international trade integration and also boost the tax revenue of the government through the payment of corporate taxes. Other spillover effects include heightened local firm development through linkages.

\subsection{The Effects FDI on Poverty Reduction-Through Job Creation}

FDI has the possibility of creating jobs as they enter the host country. These firms invest massively in the host countries and thus lead to an increase in the level of output thereby creating economic growth and development. 
Apart from investing in physical assets whereby the firms will operate, they also hire the population and train them to work in their established firms locally. Hence, there is economic growth led employment creation in the host countries thereby contributing in a reduction in poverty level.

An increase in employment as a result of foreign investment has the capacity to create further employment in other sectors through the multiplier effect. This is explained by the fact that an increase in employment will boost aggregate demand thereby putting pressure on other sectors to increase production whereby demanding more labour to work in the other sectors as well. Hence, there will be general employment creation thereby leading to a reduction in poverty level.

This mechanism is illustrated in Diagram 1 below.

However, the extent of these direct effects depends on the scale of the foreign investment, the number of people employed and trained, the extent to which the firm can acquire essential goods and services (e.g. machinery, construction engineers) locally; and the proportion of profits reinvested periodically in the subsidiary (or other local expansion) [1].

\subsection{FDI and Poverty Reduction through "Value Chain Multiplier Effects"}

The transnational companies are part of a value chain. There are both backward and forward production linkages with domestic firms and other sectors for example through subcontracting systems between the foreign firm and local subcontractors who may supply components or semi-finished goods to the foreign firms [2]. These linkages boost economic activities in the host countries and create employment in supplier and distributor firms. Overall, the initial FDI leads to a series of spillovers to the country in terms of employment creation and economic growth. The extent of the value chain multiplier effect depends on the extent to which the value chain linkages are in the host country. However, the indirect employment creation effect of FDI is often seen to be stronger than its direct employment creation effects. On an empirical ground, Aaron [3] found that FDI has contributed 26 million jobs in developing countries worldwide. For instance, it was found that for every one direct job created by foreign investors, approximately 1.6 extra jobs were indirectly created through linkages between FDI and local sectors. Hence, through the value chain multiplier effect of FDI, employment is being created both directly and indirectly which ultimately can contribute towards poverty reduction.

\subsection{FDI and Poverty Reduction through Economic Growth}

Economic growth is considered to be an important requirement to reduce poverty level in a particular country. The study by Dollar and Kraay [4], argued that economic growth tends to increase the incomes of those down the income ladder/poor, proportionately with overall economic growth. FDI is seen to be an important ingredient of growth for the host countries. There are various ways through which FDI can generate growth. For instance, the best way is through the creation of jobs directly and indirectly. By so doing, foreign firms are helping the local population to get employment and thus aid in reducing poverty in the recipient countries. Secondly through linkages of production with local firms, foreign investment help to generate important spillovers in terms of

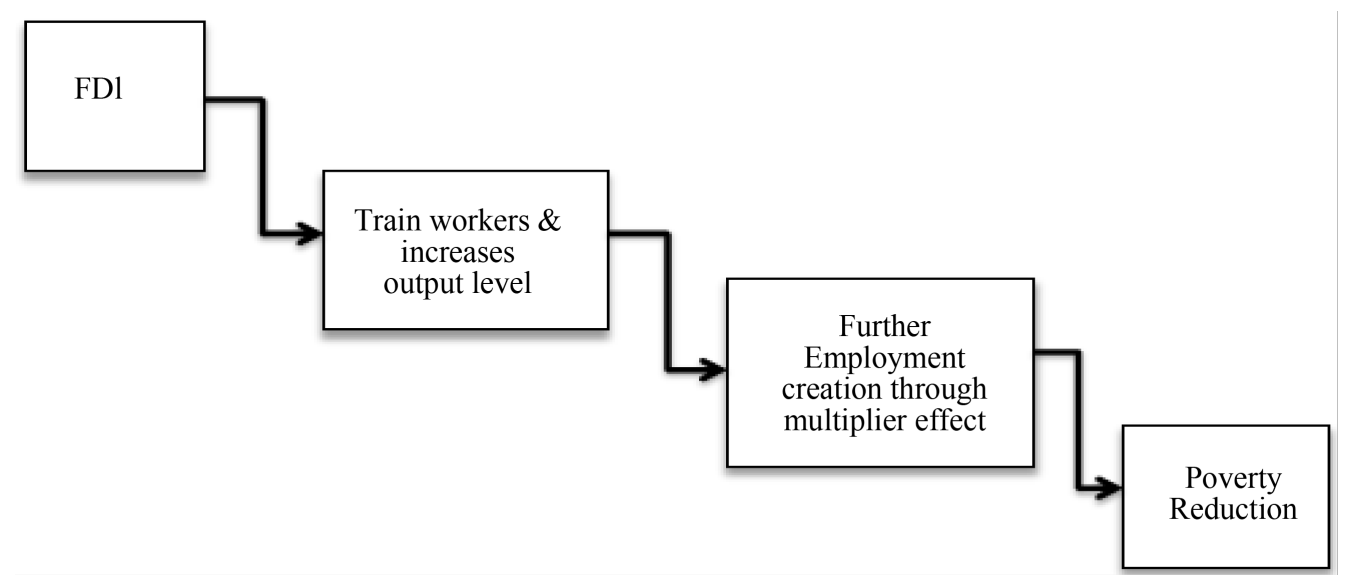

Diagram 1. FDI and employment creation through economic growth. Source: By author/s. 
technology transfer and knowledge transfer that boost the overall productivity and efficiency in the host countries. Overall, these spillovers effect generate important levels of growth and poverty reduction in countries hosting FDI.

Moreover, with FDI the level of competition increases and this ultimately boost the quality of physical capital and efficiency of investment in the host countries, and thereby boosting the effectiveness of local investment. This results in an increase in the ratio of investment to GDP and consequently the increase in investment leads to an increase in the demand for goods and services of the other sectors through the multiplier and accelerator effects. Since output in the country increases, this indicates higher economic growth. The transmission mechanism is depicted on Diagram 2 below.

On the empirical ground, Hansen and Rand [5], for instance investigated the impact of FDI on GDP using a two variable autoregressive model for 31 developing countries over the period 1970-2000. The study did provided evidence of a positive link between FDI and economic growth in the long run. Moreover, it was noted that the study by Bende-Nabende [6] showed that FDI can lead to higher investment in the Philippines and Thailand. However, such investment did not translated in higher output levels in these countries. Hence, it was concluded that FDI does not necessarily generate economic growth in the recipient countries. For instance, the problems of foreign investment are mainly seen through its tendency of generating crowding out effects on local firms. Hence, there might be more harm caused by these firms to society than benefits. They can force local firms out of business and capture the local markets. Hence, the argument about FDI leading on economic growth in host countries depends on a country by country basis.

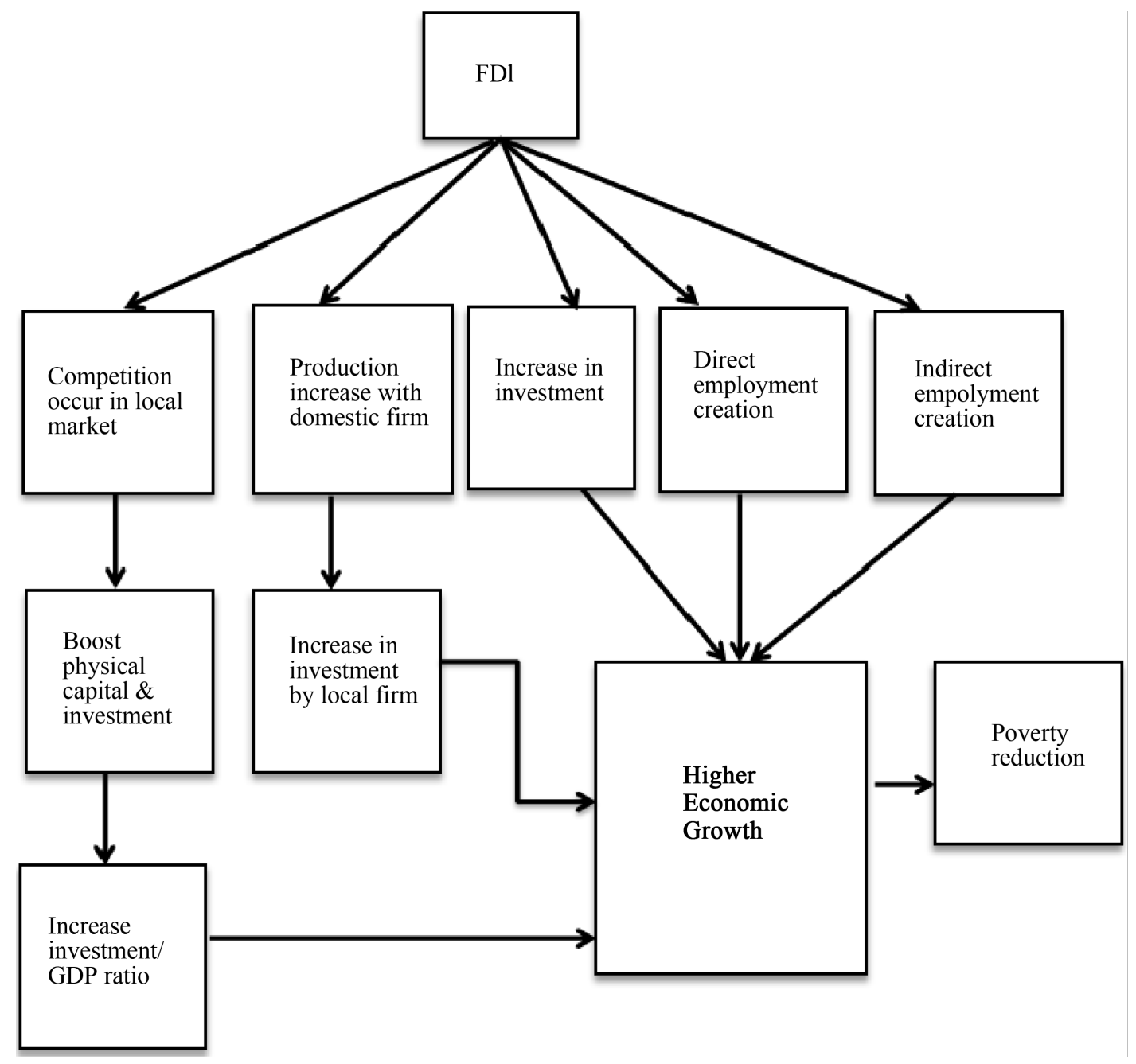

Diagram 2. Source: By author/s. 
If there is economic growth being registered with the inflow of foreign investment in the host country, there might be a reduction in poverty level. However, there are a number of countries where this has not happened. For example the study of Carkovic and Levin [7] have analysed the link between FDI and economic growth for 72 countries. The results does not support the fact that FDI increase economic growth. Klein [8], argued that FDI can generate several more benefits than just generating economic growth for the recipient countries. These are quoted below:

FDI has the potential to improve the quality of growth by

- reducing the volatility of capital flows and incomes;

- improving asset and income distribution at the time of privatization;

- helping improve social and environmental standards;

- helping improve social safety nets and basic services for the poor.

Other important factors required to reduce poverty include the quality of institutions in the recipient countries. For instance the better the institutional quality, the higher will be poverty reduction. Rivera, [9] for instance, investigated the relationship between institutions on poverty reduction and the results shows that there is a strong positive link between institutional quality and poverty reduction. Moreover, the study also showed that income growth is a necessary but not sufficient condition for reducing poverty. Similarly, the study by Chong and Calderon [10], also suggest that institutional effectiveness will reduce poverty. The indicators of institutional development as index of expropriation risk and bureaucracy quality were taken into consideration. Hence, it can be concluded that economic growth does not always lead to poverty reduction.

\subsection{FDI and Poverty Reduction through Technological and Managerial Spillovers}

With inflow of foreign investment there is considerable diffusion of new technologies, innovations, knowledge, new best practices and other intangible assets throughout the economy of the recipient countries. Such technology diffusion can lead to an improvement in efficiency and productivity in the host country thereby resulting in an increase in income per worker and thus result in poverty reduction.

This transmission mechanism is depicted in Diagram 3.

The investigation by Graham [11] whose study was based on the economic consequences of FDI for example concludes, that FDI contributes to an increase productivity and efficiency in resource allocation of the host countries mainly because such investment generate a transfer of new technology, knowledge and other intangible assets. Moreover, an analysis of the literature shows that FDI contribute to generate more jobs in the recipient countries and also very importantly it helps to boost investment in human capital through the transfer of knowledge to the local workforce. However, if top hierarchy positions are occupied by expatriates then the diffusion of knowledge is less likely to occur [12].

Hence, as depicted in Diagram 3 and proved through different studies, an increase in FDI can lead to an increase in productivity and efficiency in the recipient country through a transfer of technology and knowhow. This important spillover effect of FDI can thus generate social welfare or a reduction in poverty level in the host countries.

\subsection{FDI and Poverty Reduction through Allocation of Tax Revenue}

With more foreign investment flowing in a particular country, the amount of tax revenue received by the government will increase. This occurs mainly through an increase in corporate taxes. As a result, the government has more funds to finance social development programmes. These can include an investment in social security benefits, financing small enterprises or even provide more assistance to those down the income ladder. However, to realize such benefits there are certain pre conditions required. For instance, corporate taxes should not be too high else it will discourage foreign investors from investing in the country. Also, it depends on the agreements made by the government and the foreign firms in terms of encouraging them to invest in the country. It has been argued that in some cases foreign firms tend to manipulate the government and demand various incentives before coming in the country. These incentives might include low corporate taxes. In such situations the government will not be able to generate enough of tax revenues from the foreign firms to invest in social programmes. Also, tax revenue will help to reduce poverty only if the government of the recipient countries channels the fund towards poverty alleviation oriented programmes. Diagram 4 illustrates the transmission mechanism between FDI, tax revenue and poverty reduction. 


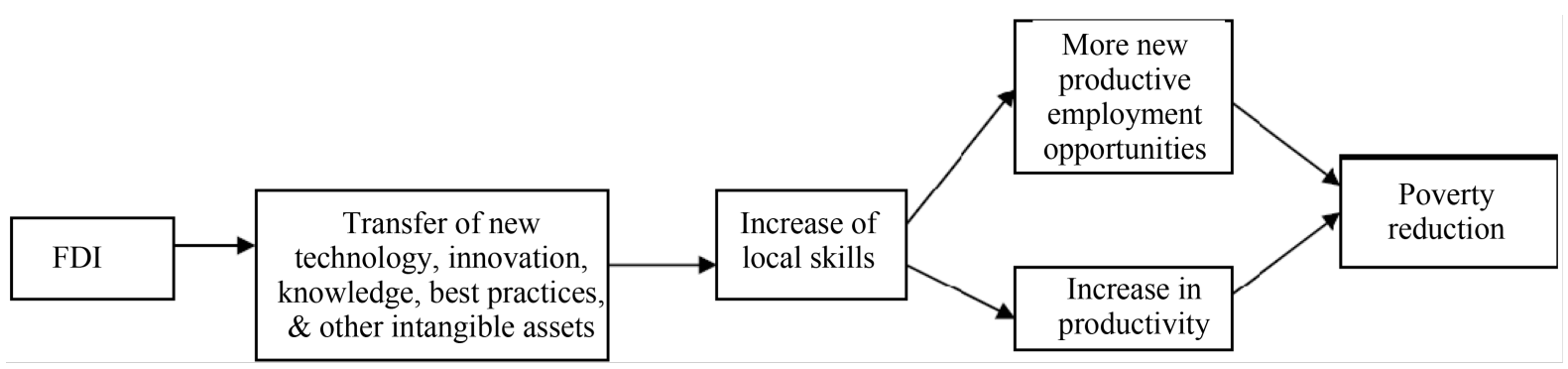

Diagram 3. Source: Tambunan, 2005 [2].

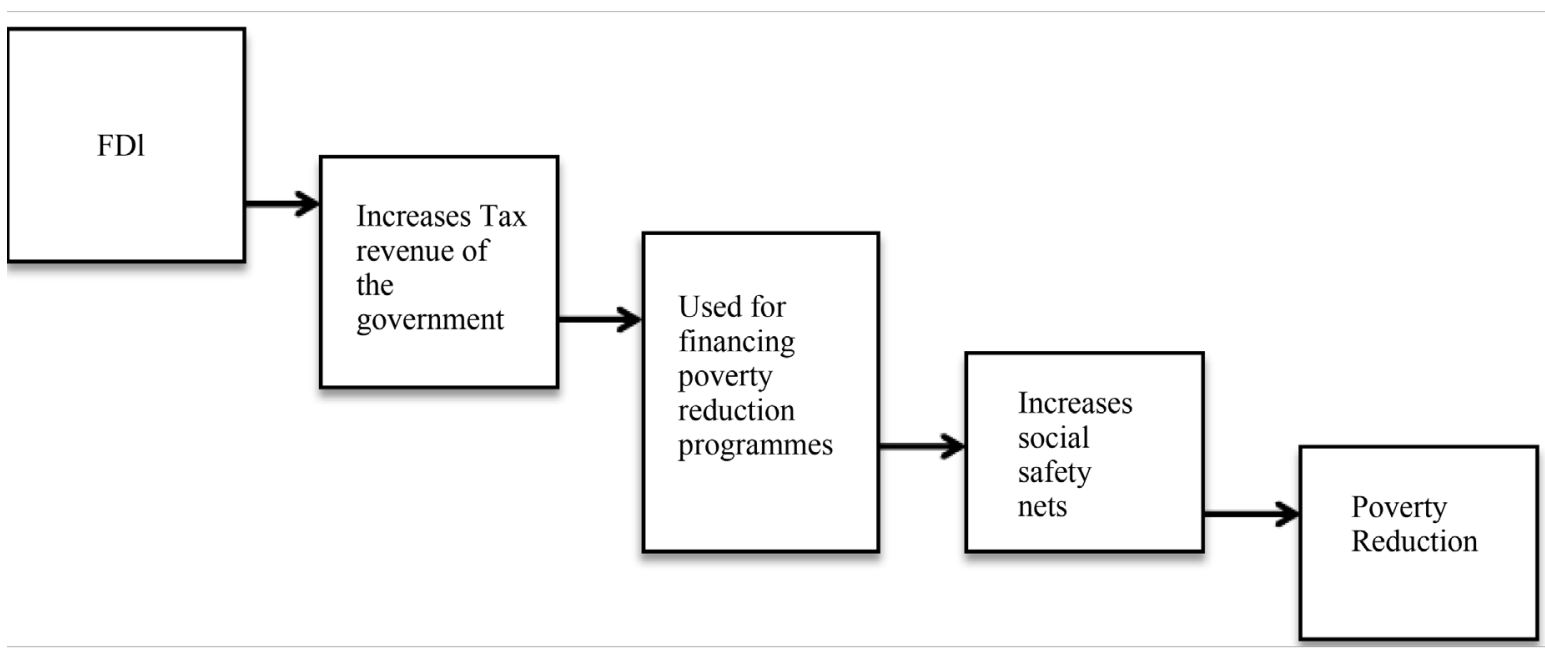

Diagram 4. Source: By author/s.

Other studies like Shahbaz \& Aamir [13], have argued that the most important determinant of the impact of FDI on poverty reduction is the economic and political environment prevailing in the host countries. Hence, in order to maximize the social benefits from foreign direct investment, host countries must ensure that they have favourable economic and political conditions. However, many critics of FDI claim that foreign companies have a tendency to flow in countries with low wages, low taxes and weak environmental and social standards.

Another strand of literature has used the human development index to capture poverty reduction. For instance, the study by Gohou and Soumare [14] examined the effect of FDI on poverty reduction in five regions of Africa between 1990 and 2007. They used the Human development index as an indicator of poverty reduction and welfare. Their findings show that indeed FDI reduces poverty and mostly in poorer countries than in richer ones.

\section{Overview of FDI \& Poverty in Mauritius}

\subsection{Evolution of Poverty in Mauritius}

Since independence in 1968, Mauritius has advanced from a low-income, mono crop economy to a middleincome and well diversified economy. Where initially, the economy of Mauritius was mainly agricultural based; now other sectors has flourish such as the industrial, financial, and tourism sectors. Moreover, the economy has registered strong growth over the last several decades. As a result, several improvements have been observed in the economy such as more equitable income distribution, increased life expectancy, lowered infant mortality, and a much-improved infrastructure.

The main drivers of growth for the economy has been identified in the sugar, tourism, textiles and apparel, and financial services sectors, as well as fish processing, information and communications technology, and hospitality and property development. In 2014, Mauritius has been considered as an upper middle income country with gross national income per capita at $\$ 9290$. Referring to poverty data, the poverty rate is seen to be lower as compared to other sub Saharan African countries. 
In Mauritius, a household budget survey (HBS) is conducted every five years by Statistics Mauritius. It establishes the most consistent data source for household income and expenditure data. The main objective of the survey is to get up to date information on the consumption pattern of Mauritian households (Mauritius Statistics, 2014).

\subsection{Level of Median Household Income}

The relative poverty line used for poverty analysis in Mauritius is based on half median household income. The poverty line can be set at different level of median income. The most commonly used levels of income are at $40 \%, 50 \%$ and $60 \%$ median income for the island. The poverty incidence based on these levels of median income is presented in Table 1.

The income gap ratio presented in the above table shows an indicator of the depth of poverty and measures the difference between the poverty line and the mean income of the poor. This measure of poverty is expressed as a ratio of the poverty line. The data shows that the proportion of poor people has declined from 1996/97 to 2001/02; however, it has increased during the period 2006/2007 and 2012. Referring to the income gap the situation of the poor has deteriorated from 1996 to 2012. This is indicated by an increase in the income gap ratio from $21.0 \%$ to $24 \%$.

On the other hand, the poverty gap ratio indicates the total resources needed to bring all the poor out of poverty. Thus this is seen as a crucial indicator that can be used for programmes and policies concerning poverty reduction. The poverty gap ratio for the island was $2.3 \%$ in 2012. Moreover, the welfare in Mauritius is largely influence by the socioeconomic characteristics of its head, mainly gender characteristic of the head, education attainment and economic activity that is their employment status.

Table 2 summarises the selected indicators of welfare for the island.

It can be noted that the illiteracy rate has declined from 1990 to 2011. Also, the table shows an increase in educational attainment. However, referring to the unemployment rate, it is noted that it has increased from 5.3\% to $7.5 \%$. Hence, though educational attainment has increased, this has not really contributed to the creation of job in the country. Therefore, it can be argued that there is a mismatch of education and employment need in Mauritius.

\subsection{Evolution of HDI in Mauritius}

Mauritius is often regarded as one of the richest and very successful African economy. The success of the Mauritian economy can largely be attributed to its policy of trade openness, given its small domestic market. The traditional ingredients of growth have been sugar, textile, and tourism. The economy also diversified into financial services and information and computer technologies, keeping the traditional sector base. The country tried to move up market, targeting higher value production. The main exports of Mauritius remain textiles and sugar in the manufacturing sector and tourism and financial services in the services sector.

Table 1. Indicators of relative poverty, Republic of Mauritius 1996/97, 2001/02, 2006/07 and 2012.

\begin{tabular}{|c|c|c|c|c|}
\hline & $1996 / 97$ & 2001/02 & 2006/07 & 2012 \\
\hline $\begin{array}{c}\text { Relative poverty line (Rs) } \\
\text { per adult equivalent per month }\end{array}$ & 2004 & 2804 & 3821 & 5652 \\
\hline Estimated number of households in relative poverty & 23,800 & 23,700 & 26,100 & 33,600 \\
\hline Proportion of households in relative poverty (\%) & 8.7 & 7.7 & 7.9 & 9.4 \\
\hline Estimated number of persons in relative poverty & 92,700 & 93,800 & 105,200 & 122,700 \\
\hline Proportion of persons in relative poverty (\%) & 8.2 & 7.8 & 8.5 & 9.8 \\
\hline Income gap ratio (\%) & 21.0 & 22.6 & 21.9 & 24.0 \\
\hline Poverty gap ratio (\%) & 1.7 & 1.8 & 1.9 & 2.3 \\
\hline $\begin{array}{c}\text { Annual amount required to move people } \\
\text { out of relative poverty (RsMn) }\end{array}$ & 300 & 450 & 700 & 1300 \\
\hline
\end{tabular}

Source: Household budget survey 1996/97, 2001/02, 2006/07 and 2012. 
Table 2. Selected indicators on education and employment, Republic of Mauritius-1990, 2000 \& 2011.

\begin{tabular}{|c|c|c|c|}
\hline & 1990 & 2000 & 2011 \\
\hline Illiteracy rate ${ }^{1}(\%)$ & 19.2 & 14.5 & 9.9 \\
\hline Percentage population aged 6 to 11 years not attending school (\%) & 3.4 & 1.0 & 0.2 \\
\hline Percentage population aged 12 to 19 years not attending school (\%) & 51.4 & 36.9 & 19.1 \\
\hline $\begin{array}{l}\text { Percentage population aged } 18 \text { years and over without an } \\
\text { SC qualification (\%) }\end{array}$ & 83.1 & 77.0 & 65.3 \\
\hline Unemployment rate $^{2}(\%)$ & 5.3 & 8.9 & 7.5 \\
\hline $\begin{array}{l}\text { Percentage of employed persons aged } 16 \text { years and } \\
\text { over engaged in low }{ }^{3} \text { occupations }\end{array}$ & 47.7 & 39.9 & 27.8 \\
\hline
\end{tabular}

Source: Housing and Population Census 1990, 2000 \& 2011. ${ }^{1}$ Refers to population aged 12 years and over in 1990 and to population aged 10 years and over in 2000 and 2011. ${ }^{2}$ Refers to population aged 15 years and over in 1990 and to population aged 16 years and over in 2000 and $2011 .{ }^{3}$ Refers to following occupation groups of the International Standard Classification of Occupations (ISCO). ISCO 8: Plant \& Machine operators \& Assemblers. ISCO 9: Elementary occupations Figures for 1990 and 2000 refer to population aged 15 years and over.

In 2005, the country introduced bold reforms which changed the landscape of business activities in Mauritius and these ranged from changes in policies to ease investment and business environment, to labour reforms, liberalisation of tariff (Duty Free Island concept) and non-tariff barriers, The economy also experienced massive investment in infrastructure and movement towards higher value added production. As such, it may safely be argued that these reforms have contributed in making the economy stronger and more competitive

Regarding welfare in the country, it is noted that the human development index has been increasing during the last decades. The HDI is a composite measure of three basic dimensions of human development: health, education and income. According to the United Nations Development Programme, the Human Development Index of Mauritius has a score of 0.771 in 2014 which is quite close to the HDI of North African economy at 0.784 . Also, Mauritius has been ranked second in Africa after Libya on human development, with the two countries achieving global ranks of 63rd and 55th respectively in the high human development category, out of 187 countries in all which were ranked on the Human Development Index in 2014.

The evolution of HDI for Mauritius compared to Sub Saharan Africa and the world is shown in Diagram 5 below. It can be seen that Mauritius has a higher score on HDI as compared to Sub Saharan Africa.

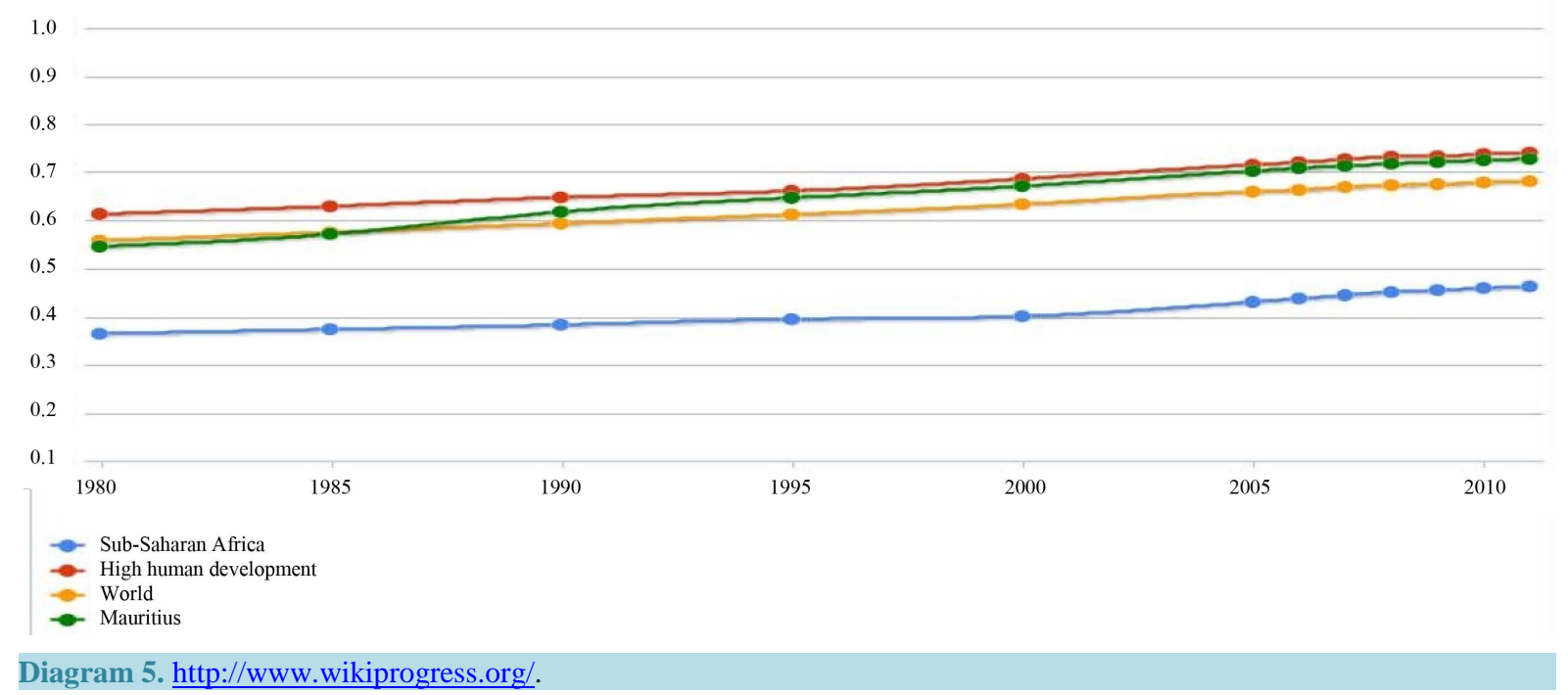

\subsection{FDI in Mauritius}

Foreign direct investment has been constantly growing during the recent years. However, with the advent of the 
global economic crisis, foreign capital flows have fallen slightly and in 2012 it has ultimately recovered. Referring to estimations, FDI in Mauritius has increased by 15\% during the first two quarters of 2013. Mauritius moreover ranked among the best twenty countries favoured for investment in the world. Also, Mauritius rank 8th Worldwide and 1st in Africa in terms of economic freedom as per Heritage Foundation.

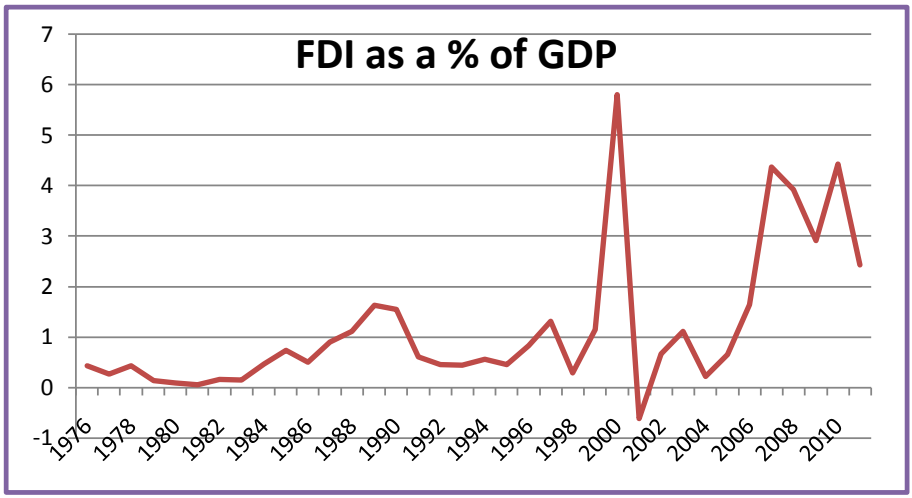

In terms of sectorial analysis, the tourism sector has attracted more foreign capital, mainly in the Integrated Resort Scheme, relating to the construction of luxury villas, golf courses and other amenities in the resort areas. The foremost investors are Great Britain, France, South Africa, the United States, Madagascar and Italy. Table 3 below shows the amount of FDI flow in the different sectors of the economy.

Table 3. Sectorial analysis of foreign capital.

\begin{tabular}{|c|c|c|c|c|c|c|c|}
\hline DESCRIPTION & 2007 & 2008 & 2009 & 2010 & 2011 & 2012 & 2013 \\
\hline Agriculture & 18 & 447 & - & - & 177 & 9 & 36 \\
\hline Manufacturing & 271 & 149 & 485 & 63 & 54 & 426 & 17 \\
\hline $\begin{array}{l}\text { Electricity, gas, steam and } \\
\text { air conditioning supply }\end{array}$ & - & - & - & 2 & 1 & 0 & 16 \\
\hline Construction & 45 & 68 & 211 & 1292 & 2094 & 1775 & 513 \\
\hline $\begin{array}{l}\text { Wholesale and retail trade, repair of } \\
\text { motor vehicles and motorcycles }\end{array}$ & 38 & 103 & 291 & 125 & 21 & 221 & 268 \\
\hline Transportation and storage & - & 14 & 10 & 110 & 4 & 22 & - \\
\hline $\begin{array}{l}\text { Accommodation and Food } \\
\text { service activities }\end{array}$ & 3189 & 1348 & 1850 & 836 & 579 & 645 & 31 \\
\hline Information and communication & 18 & 8 & - & 235 & 76 & 64 & 13 \\
\hline Financial and insurance activities & 4056 & 4564 & 1371 & 4645 & 1646 & 4348 & 342 \\
\hline Real estate activities & 3820 & 4525 & 4305 & 3422 & 4580 & 5122 & 1438 \\
\hline Of which IRS/RES & 2791 & 2637 & 2074 & 2033 & 3352 & 4228 & 1166 \\
\hline $\begin{array}{l}\text { Professional, scientific } \\
\text { and technical activities }\end{array}$ & - & - & - & 404 & 217 & 36 & 1 \\
\hline Education & 30 & 74 & 125 & 18 & 4 & - & 2 \\
\hline Human health and social work activities & 29 & 120 & 145 & 2732 & - & - & - \\
\hline Arts, entertainment and recreation & & & & 62 & 3 & & \\
\hline TOTAL & 11,514 & 14,420 & 8793 & 13,946 & 9456 & 12,668 & 2677 \\
\hline
\end{tabular}




\section{Research Method}

The main purpose of the present study is to investigate the impact of foreign direct investment on poverty reduction in Mauritius over the time period spanning from 1980 to 2013. To construct the econometric model, reference has been made to various past studies on this issue such as, Hung (2005), Seetanah et al. [15] \& Gohou et al. [16]. The model are specified below;

$$
\text { Welfare }=\alpha+\beta \times \text { FDI }+\Sigma \gamma \mathrm{t} \times \text { Economic Vars }+\varepsilon,
$$

where welfare is measured by HDI, FDI is measured by the ratio of FDI/real GDP and the control variables are the economic variables as specified below;

$$
\text { Model 1: WELFARE/HDI = f (FDI, GOVSP, UNEM, OPEN, DEBT, CPI) }
$$

Model 1 is used to analyse the impact of FDI on poverty reduction.

\subsection{Variables Definition}

\subsubsection{Dependent Variable}

Since there are limited data available on poverty headcount in Mauritius, a welfare proxy is used to measure the extent of poverty reduction in the country. For instance, following the paper by Gohou et al. [14], who used the HDI index as a proxy of social welfare as well as poverty reduction for the case of Africa; same is being done in this investigation for the case of Mauritius.

According to the UNDP, "The HDI-human development index-is a summary composite index that measures a country’s average achievements in three basic aspects of human development: health, knowledge, and a decent standard of living. Health is measured by life expectancy at birth; knowledge is measured by a combination of the adult literacy rate and the combined primary, secondary, and tertiary gross enrolment ratio; and standard of living by GDP per capita (PPP US\$).

\subsubsection{Independent Variables}

The variable of interest is the foreign direct investment variable as measured by FDI and the proxy used is net FDI inflow as a percentage of real GDP. As argued by various scholars, FDI has the potential of reducing poverty in a country through the direct and indirect channel. The direct channel includes the creation of employment when FDI flow in a particular country. Furthermore, an increase in employment as a result of foreign investment has the capacity to create further employment in other sectors. As mentioned in the literature review, an increase in employment will increase aggregate demand and in so doing, there is pressure on other sectors to increase production whereby demanding more labour to work in the other sectors as well. As a result, there will be general employment creation thus leading to a reduction in poverty levels.

Other control variables include government spending as a percentage of GDP. Normally the more the government expenditure in a country it will contribute to increase welfare of the population. Generally, the government spends on public and merit goods which are both required to boost standard of living. Hence, a positive sign for this variable is expected. Moreover, we have also included the variable openness as measured by the sum of imports and exports to GDP. The more opened an economy, the wider will be the range of goods available to the population and may thus boost welfare in a country. For instance, Winters [16] found that trade reform in general increases the income of the poor as a group and that the transition costs are generally small relative to the overall benefits. Nonetheless, there are circumstances where the short-run effects of trade openness or liberalisation on the poor are negative.

The variable government debt as a percentage of GDP is also included as another independent variable. For instance, the more indebted an economy is, more resources will be spent in the repayment of debts rather than investing in social programmes. Hence, it is expected that government debt will negatively influence welfare of the population. Also, unemployment is another major problem that will negatively influence welfare of the population. Unemployment is seen as a social evil. Hence, unemployment is another control variable added. Moreover, even inflation as captured by consumer price index will have a negative impact on the welfare of the population. Inflation is also a measure of macroeconomic stability. If prices are increasing more rapidly than income, then consumers will find their income lagging behind their expenditure thereby affecting their living standards. In period of inflation, those down the income ladder and fixed income earners are mostly affected. 
The econometric specification can be written as follows:

$$
\begin{aligned}
\operatorname{lnHDI}_{t}= & \alpha_{0}+\beta_{1} \operatorname{lnFDI}_{t}+\beta_{2} \operatorname{lnGOVTSP}_{t}+\beta_{3} \operatorname{lnUNEM}_{t} \\
& +\beta_{4} \operatorname{lnOPEN}{ }_{t}+\beta_{5} \ln \operatorname{lnBBT}_{t}+\beta_{6} \operatorname{lnCPI}_{t}+\mu_{t}
\end{aligned}
$$

where $t$ denotes the time dimension and logarithm is applied to the variables for ease of interpretation (that is in percentage terms).

Data sources: UNDP, Statistics Mauritius \& Bank of Mauritius. The descriptive statistics are reported in Appendix (Table A1).

\subsection{Estimation Issues}

A VAR approach is used to explain the relationship between FDI and poverty reduction. Such an approach does not impose a priori restriction on the dynamic relations among the different variables. It resembles simultaneous equation modeling, whereby several endogenous variables are considered together. Hence, the VECM linking short term and long term causality between FDI and poverty reduction or welfare is set as follows:

$$
\begin{aligned}
\Delta \operatorname{lnHDI}_{t}= & \alpha_{0}+\sum_{j=1}^{n} \alpha_{1} \Delta \operatorname{lnFDI}_{t-j}+\sum_{j=1}^{n} \alpha_{2} \Delta \operatorname{lnGOVTSP}_{t-j}+\sum_{j=1}^{n} \alpha_{3} \Delta \operatorname{lnUNEM}_{t-j} \\
& +\sum_{j=1}^{n} \alpha_{4} \Delta \operatorname{lnOPEN} \ln _{t-j}+\sum_{j=1}^{n} \alpha_{5} \Delta \operatorname{lnDEBT}_{t-j}+\sum_{j=1}^{n} \alpha_{6} \Delta \operatorname{lnCPI}_{t-j}+\eta \mathrm{ECT}_{t-1}+\varepsilon_{t}
\end{aligned}
$$

The coefficient of the error correction term $\left(\mathrm{ECT}_{t-1}\right)$ indicates whether there exists a short run relationship among the time series variables.

Furthermore, applying regression on time series data may generate spurious results [17] [18] given the possibility of non-stationarity data. As such, undertaking a check as to the stationarity of data is a prerequisite for applying the co-integration test. As a result, the Augmented Dickey-Fuller (ADF) test [19] and the Phillips-Perron test [20] were applied.

\section{Analysis of Findings}

From the application of the augmented Dickey-Fuller (ADF) [19] and Phillips-Perron (PP) [20] unit-roots tests, we observe that all the variables are integrated of order 1 and stationary in first difference. The Johansen Maximum Likelihood approach is subsequently used to test the presence of cointegration in a vector error correction model. Trace statistics and maximal eigenvalue confirm the presence of co-integration and we thus conclude that a long run relationship exists in the above specification.

\subsection{Empirical Results}

The long run estimates of Equation (2) are reported in Table 4 below.

Analysing the long run results, interesting outcomes can be observed from the table. For instance, the main variable of interest which is FDI is seen to have a positive impact on welfare. Hence, we can note that an increase in the level of foreign direct investment in the country contribute to boost the level of welfare in the country. Since, HDI is a composite index of education level, health and economic performance, then one can

\begin{tabular}{cc} 
Table 4. The long run estimates. & \\
\hline & Model 1 \\
\hline Dependent variable & Ln HDI $_{\mathrm{t}}$ \\
Ln FDI & $0.014025^{* * *}$ \\
Ln GOVTSP $_{\mathrm{t}}$ & $0.143711^{* *}$ \\
Ln UNEM $_{\mathrm{t}}$ & $-0.061783^{* *}$ \\
Ln OPEN $_{\mathrm{t}}$ & $0.162742^{*}$ \\
Ln DEBT $_{\mathrm{t}}$ & $-0.011962^{* * *}$ \\
Ln CPI $_{\mathrm{t}}$ & 0.147201 \\
Constant & 3.372792 \\
\hline
\end{tabular}

${ }^{*}$ Indicates the significance at $10 \%,{ }^{* *}$ significance at $5 \%$ and ${ }^{* * *}$ significance at $1 \%$. 
argue that FDI inflow in Mauritius has positively contributed towards boosting these welfare determinants in Mauritius. This result is in line with Gohou et al. [14]. As discussed in the literature review, FDI has the potential to boost welfare or reduce poverty through various transmission mechanisms. For instance, FDI flows in the country generate various spillovers effects. Like an increase in the production of goods and services, technology spillovers and transfer of skill and know how. Relating this result to the Mauritian economy, it has been observed that FDI inflow has been significant in various sectors of the country and this has helped the economy to register an increase in output, as well as sectorial development such as the development of the tourism industry, the real estate sector as well as the financial sector above many others. Moreover, the government has been consistently devising policies to attract foreigners to invest in the country. The business environment prevailing in Mauritius is as well favourable for FDI.

Referring to the results obtain on government spending, we can argue that it has positively contributed to boost welfare in the country. Alternatively, we can also say that an increase in government spending has led to a reduction in poverty level in the country in the long run. For instance the Mauritian government spends a lot on public and merit goods. Several ministries are directly or indirectly involved in programmes aiming at reducing social exclusion and alleviating poverty. For instance, the government's National Action Plan for Poverty Alleviation has been prioritizing the democratization of economic growth. In order to revitalise vulnerable communities out of poverty in a sustainable manner, it establishes pro-poor policies and planning in the sectors of the economy touched by the reforms, and focuses on diversifying the economy to achieve strong and sustained growth. Other strategic measures under the action plan include strengthening the education system (in particular, supporting vocational training in new skills for former textile workers and sugar cane planters). The strategy also aims to reduce poverty by providing regional financial services and targeted investment, including support for microenterprises and microfinance institutions (IFAD in Mauritius, 2010).

Further analysing the results from the regression, we can note that unemployment has a negative link with HDI. Hence, as expected, as the level of unemployment increases it will result in an increase in poverty. Also, unemployment affects the rate of economic growth, which may ultimately push the economy towards a depression. Likewise, we can observe from the results that debts in the country will affect welfare negatively. When a country is highly indebted, most of its resources are used to finance the debts rather than investing in poverty reduction programmes. Normally, developing countries depend a lot on the government for investment in social security and related programmes that will alleviate poverty and boost social welfare. However, high debts prevent the government to do so.

Analysing the relationship between trade openness and welfare in Mauritius, we can observe that an increase in openness has had a positive influence. For instance with trade openness such goods and services can enter the country that is used for its development and to maximize welfare. For example, as mentioned in Powell et al. [21] these can be in the form of medical equipment and better-trained medical staff that can improve the general health of the population and thus contribute to human development. An additional contributing aspect is efficient water treatment facilities and sewer systems. Equally, imports of modern agricultural equipment, technical services, and farming methods can increase a nation's capacity to produce food. Openness to the exchange of scholars and students can improve the quality of education. It should be noted that some if not all of these factors also enhance the growth capacity of the economy as they represent investment in the country's social and economic infrastructure.

Inflation on the other hand is seen to have an insignificant impact on welfare here. This result is in contrast with theory propounding that the higher the inflation level the more welfare will be affected. However, the rate of inflation has been increasing in Mauritius but the country also has very dynamic trade unions who bargain for increases in income. This argument can partly explain our result.

\subsection{The Short Run Regression}

In the presence of co integration we subsequently estimate a VECM including the error correction term which should allow for an investigation of the dynamic nature of the model. The VECM specification forces the long run behavior of the endogenous variables to converge towards their co integrated relationships, which accommodates short run dynamics. In this study, the VECM is estimated using an optimum lag length of 1 . The empirical results of the short run estimates for model 1 of the VECM are displayed in Table 2.

Table 5 is a composite table, where each column can be viewed and analyzed as an independent function, that 
Table 5. Short run results.

\begin{tabular}{|c|c|c|c|c|c|c|c|}
\hline $\begin{array}{c}\text { Error } \\
\text { correction model }\end{array}$ & $\Delta \mathbf{h d i}_{t}$ & $\Delta \mathbf{f d i}_{t}$ & $\Delta$ govtsp $_{t}$ & $\Delta$ unem $_{t}$ & $\Delta \operatorname{spen}_{t}$ & $\Delta$ debt $_{t}$ & $\Delta \mathbf{c p} \mathbf{i}_{t}$ \\
\hline Constant & $0.0010^{* * *}$ & 0.4896 & 0.0102 & $0.0240^{*}$ & $0.0697^{*}$ & 0.5063 & $0.0123^{* *}$ \\
\hline$\Delta \mathrm{hdi}_{t-1}$ & $0.8786^{* *}$ & -3.887 & 0.8303 & -11.962 & 2.0244 & -5.9381 & 3.4149 \\
\hline$\Delta \mathrm{fdi}_{t-1}$ & $0.0003^{* * *}$ & $0.2406^{*}$ & $-0.0302^{* *}$ & $-0.0916^{* *}$ & -0.0046 & $-0.1017^{* *}$ & $0.0040^{* * *}$ \\
\hline$\Delta$ govtsp $_{t-1}$ & $0.0025^{* * *}$ & 3.5677 & 0.0344 & 0.7733 & 0.0031 & -1.8647 & 0.0858 \\
\hline$\Delta$ unem $_{t-1}$ & $-0.0015^{* * *}$ & 0.5563 & $0.0411^{* *}$ & 0.4154 & 0.0499 & -1.8647 & 0.0858 \\
\hline$\Delta$ open $_{t-1}$ & -0.0061 & 1.7792 & -0.1297 & 0.3391 & 0.0986 & 1.6499 & 0.0886 \\
\hline$\Delta$ debt $_{t-1}$ & $-0.0015^{* *}$ & -0.2596 & -0.0132 & $-0.07026^{* *}$ & $-0.0461^{* *}$ & -0.3406 & $-0.0242^{* *}$ \\
\hline$\Delta \mathrm{cpi}_{t-1}$ & $-0.0002^{* *}$ & 1.1229 & -0.1496 & 1.07392 & -1.0013 & 0.3778 & 0.2592 \\
\hline$\sqrt{t-1}$ & $-0.0517^{* * *}$ & 15.221 & $-0.0418^{*}$ & $-3.2862^{* *}$ & 0.2059 & $-12.1223^{*}$ & $-0.2337^{*}$ \\
\hline $\mathrm{R}^{2}$ & 0.98 & 0.30 & 0.46 & 0.78 & 0.54 & 0.45 & 0.58 \\
\hline
\end{tabular}

"Significant at $10 \%,{ }^{* *}$ Significant at $5 \%,{ }^{* * *}$ Significant at $1 \%$.

is, each column in the table corresponds to an equation in the VECM. The variable named in the first cell of each column is viewed as the dependent variable. The estimated coefficient of the explanatory variables is reported in the cells. Our focus will be on the first column.

Analysing the short run results and the regression equation with human development index as the dependent variable, it may be argued that FDI is an important contributor to welfare or poverty reduction in the present instance, though the coefficient being smaller which tends to support the argument that such type of investment takes time to have its full effect on the economy. In this present instance, a 10 percentage point increase in the growth rate of foreign capital flows leads to a 0.003 percentage increase in welfare. Additionally but similar to the findings uncovered for the long run equation, the government spending variable is also positive and significant. It supports the fact that even in the short run an increase in government spending will boost social welfare. More so, the level of debt and inflation influences welfare negatively in the short run. An increase in price level affects the poor, mainly those with fixed income and pensioners. Regarding the openness variable, we can further see that the results are different from the long run ones. In the short run, openness does not increase social welfare.

Furthermore and as discussed previously, the VAR/VECM framework allows us to gauge more interesting insights on endogeneity issues and also allows us to detect any potential indirect effects. Whilst, our results show that FDI reduces poverty level or increases social welfare, the results reported in the above table shows however that the welfare level in the country does not influences the level of FDI. Thus, the results demonstrate that there is a uni-directional relationship which exists between FDI and social welfare. As such, one could argue that HDI, which proxies the level of development, does not really contribute towards attracting foreign investment in the country. Moreover, referring to the fifth column, it can be noted that an increase in FDI reduces unemployment level in the country. For instance, a 10 percent increase in FDI reduces unemployment by 0.9 percent. And as observed from the second column, unemployment is negatively linked to welfare. Hence, as unemployment will fall, social welfare will increase or poverty level will fall. Hence, these results are confirming the relationship between FDI and poverty reduction through the direct channel as illustrated in Diagram 1 in the literature review section (FDI reduces unemployment and a reduction in unemployment increases welfare).

Given the above, the overall results tend to provide support to the existence of a positive and significant relationship between FDI and poverty reduction, both in the short run and in the long run.

\section{Conclusions}

This study investigated the complex linkage between foreign direct investment and poverty reduction in Mauritius over the period 1980 to 2013 within a VECM framework. It provided analytical discernments into the issue by discussing the various transmission channels through which FDI can lead to the maximization of social wel- 
fare or poverty reduction. The regression results have shown that foreign direct investment has indeed contributed to reduce poverty in the country in both the short run and long run. For instance, the empirical results confirm that an increase in foreign investment leads to an increase in human development index. Since, it is a crucial element of welfare; we can thus conclude that FDI has contributed towards boosting welfare in the country or towards reducing poverty. The results further confirm a uni-directional causality between FDI and the welfare proxy.

It should be noted that the Mauritian government has devised several policies to attract FDI in various sectors of the country. This has definitely led to a transfer of technology and knowhow. Also, direct and indirect employment has also increased to a large extent. This argument is supported by the results. It is found that an increase in FDI has led to a reduction in the unemployment level in the country. Moreover, other variables contributing to welfare are government spending as well as trade openness. High debts are seen to affect the level of welfare in the country.

For instance, it is found that Mauritius has been consistently implementing pro-poor policies and reforms to protect those down the income ladder or the poor in general. Several policies have been designed to attract FDI as these are found to have several development attributes to the country. The government is playing the role of a facilitator and has always striven to create the most conducive investment environment by

- Enacting appropriate legislations.

- Building state-of-the-art infrastructure.

- Investing in human capital and introducing packages of investment incentives for the manufacturing.

- Financial services and ICT sectors (Grant Thornton Mauritius, 2015).

As a concluding note, the authors believe that the present study has contributed to the existing literature given firstly, the very scanty nature of such type of studies; and secondly, given that, to the best of our knowledge, such type of studies investigating the direct and indirect relationship between FDI and welfare and even more so focusing on a small island economy, is non-existent.

\section{References}

[1] Mirza, H., Giroud, A., Jalilian, H., Weiss, J., Freeman, N. and Than, M. (2004) Regionalisation, Foreign Direct Investment and Poverty Reduction: The Case of ASEAN. University of Bradford, School of Management.

[2] Tambunan, T. (2005) The Impact of Foreign Direct Investment on Poverty Reduction: A Survey of Literature and a Temporary Finding from Indonesia. Consultative Meeting on "Foreign Direct Investment and Policy Changes: Areas for New Research”, United Nations Conference Centre, Bangkok, 12-13.

[3] Aaron, C. (1999) The Contribution of FDI to Poverty Alleviation. Report, The Foreign Investment Advisory Service, Singapore.

[4] Dollar and Kraa (2000) Growth Is Good for the Poor. Development Research Group. The World Bank. First Draft, March 2000

[5] Hansen, H. and Rand, J. (2006) On the Causal Links between FDI and Growth in Developing Countries. The World Economy, 29, 21-41. http://dx.doi.org/10.1111/j.1467-9701.2006.00756.x

[6] Bende-Nabende, A. (1998) A Static Analysis of the Impact of FDI on the Host Developing Countries' Economic Growth: A Case for the ASEAN-5 Economies. Paper Presented at the ESRC Conference on Finance and Development, Birmingham, 7-8 September 1998.

[7] Carkovic, M. and Levine, R. (2002) Does Foreign Direct Investment Accelerate Economic Growth? http://www.worldbank.org/research/conferences/financial_globalization/fdi.pdf

[8] Klein, M., Aron, C. and Hajimichael, B. (2001) Foreign Direct Investment and Poverty Reduction. World Bank Policy Research Working Paper No. 2613, The World Bank, Washington DC.

[9] Rivera, H.D. (2009) Poverty and Institutional Quality in a Cross-Section of Countries. Georgia State University.

[10] Chong, A. and Calderón, C. (2000) Institutional Quality and Poverty Measures in a Cross-Section of Countries. Economics of Governance, 1, 123-135. http://dx.doi.org/10.1007/s101010050002

[11] Graham, E.H. (1995) Foreign Direct Investment in the World Economy. IMF Working Paper WP/95/59, Washington DC.

[12] Jenkins, C. and Thomas, L. (2002) Foreign Direct Investment in Southern Africa: Determinants, Characteristics and Implications for Economic Growth and Poverty Alleviation. Final Report, October, Globalization and Poverty Project, Centre for the Study of African Economies, University of Oxford, Oxford.

[13] Shahbaz, M. and Aamir, N. (2008) Direct Foreign Investment and Income Distribution: A Case Study for Pakistan. In- 
ternational Research Journal of Finance and Economics, 21, 7-18. http://www.eurojournals.com/irjfe_21_01.pdf

[14] Gohou, G. and Soumaré, I. (2012) Does Foreign Direct Investment Reduce Poverty in Africa and Are There Regional Differences? World Development, 40, 75-95. http://dx.doi.org/10.1016/j.worlddev.2011.05.014

[15] Seetanah, B., Ramessur, S. and Rojid, S. (2009) Does Infrastructure Alleviates Poverty in Developing Countries? International Journal of Applied Econometrics and Quantitative Studies, 6-2, 17-36.

[16] Winters, L.A. (2000) Trade and Poverty: Is There a Connection? In: Ben David, D., Nordstrom, H. and Winters, L.A., Eds., Trade, Income Disparity and Poverty, Special Study No.5, World Trade Organization, Geneva.

[17] Granger, C. and Newbold, P. (1974) Spurious Regressions in Econometrics. Journal of Econometrics, 2, 111-120. http://dx.doi.org/10.1016/0304-4076(74)90034-7

[18] Philips, P.C.B. (1986) Understanding Spurious Regression in Econometrics. Journal of Econometrics, 33, $311-340$. http://dx.doi.org/10.1016/0304-4076(86)90001-1

[19] Dickey, D.A. and Fuller, W.A. (1979) Distribution of the Estimation for Autoregressive Time Series with Unit Root. Econometrica, 49, 1057-1072. http://dx.doi.org/10.2307/1912517

[20] Phillips, P.C. and Perron, P. (1988) Testing for a Unit Root in Time Series Regression. Biometrika, 75, 335-346. http://dx.doi.org/10.1093/biomet/75.2.335

[21] Nourzad, F. and Powell, J.J. (2003) Openness, Growth, and Development: Evidence from a Panel of Developing Countries. Scientific Journal of Administrative Development, 1, 72-94.

\section{Appendix}

\section{Table A1. Descriptive statistics.}

\begin{tabular}{cccccccc}
\hline & HDI & FDI & GOVTSP & DEBT & OPENNESS & UNEM & CPI \\
\hline Mean & 0.649272 & 1.463529 & 13.52059 & 36.02059 & 118.4791 & 8.583853 & 71.74588 \\
Median & 0.654842 & 0.785000 & 13.85000 & 32.05000 & 122.0650 & 7.513000 & 63.49500 \\
Maximum & 0.733165 & 5.800000 & 14.80000 & 91.70000 & 150.0000 & 21.00000 & 148.0000 \\
Minimum & 0.546000 & -0.610000 & 10.50000 & 6.900000 & 71.25700 & 2.719000 & 18.60000 \\
Std. Dev. & 0.059988 & 1.630980 & 0.948932 & 20.85338 & 17.33548 & 5.191081 & 41.88615 \\
\end{tabular}

